\title{
Serum and CSF Nitric Oxide in Cases of Acute Meningitis
}

\author{
Rashed M. Hassan ${ }^{1}$, Soha, E. Khorshed ${ }^{1}$, Seham M. Zaki', \\ Hoda A. Ibraheem ${ }^{2}$ \\ ${ }^{1}$ Tropical Medicine Department, Faculty of Medicine, Zagazig University, Egypt \\ ${ }^{2}$ Clinical Pathology Department, Faculty of Medicine, Zagazig University, Egypt
}

Corresponding Author Soha E. Khorshed

\section{E mail: \\ sohaesmat@hotmail.c om}

Key words:Serum;CSF;Me ningitis, Nitric oxide
Background and study aim: In several cases of meningitis ; routinely used diagnostic procedures are unable to identify the cause of this disease. The aim of the present study was to differentiate between acute bacterial and viral meningitis as it is very important matter.Patients and Methods: Fifty patients who admitted to Fever Hospital were included in this study. They were classified into 2 groups according to CSF criteria, Group I (22 patients) with viral meningitis, Group II (18 patients) with acute bacterial meningitis. In addition 10 subjects were included as control group (GroupIII) .All subjects were subjected to clinical examination, routine laboratory investigation, lumbar Puncture, CSF analysis (bacteriological, cytological and chemical). Also, Nitric Oxide (NO) levels in serum and CSF were measured.
Results:The study found that serum and CSF NO levels were more highly significantly elevated in patients with bacterial meningitis than in patients with viral meningitis and controls. While there is no significant difference between patients of viral meningitis and controls. The rise of NO levels was significantly associated with protein, WBC and Creactive protein levels.Conclusion: Patients with bacterial meningitis had highly significant elevation in the serum and CSF levels of NO. Their levels were correlated with markers of inflammation as CRP, WBC and protein level of CSF. Serum NO examination is an easy, rapid and cheap test. It can be measured in acute meningitis without waiting the results of culture to determine the nature of infection either viral or bacterial.

\section{INTRODUCTION}

Meningitis is an inflammation of the cerebrospinal membranes that may develop from infectious or noninfectious etiology. Although the etiologies are different, clinical symptoms and signs are similar in meningitis [1]. Acute meningitis is a medical emergency mainly caused by infection with viruses or bacteria [2]. Viral meningitis is usually relatively mild and clears up within a week or two without specific treatment [3]. By contrast, acute bacterial meningitis $(\mathrm{ABM})$ has characteristics of rapid progression and a high mortality rate as well as having the potential of forming permanent neurological or audiological sequelae [4].

Routine laboratory analysis of cerebrospinal fluid (CSF) is not efficient enough to discriminate between etiologies especially in the early phase of the disease [5,6]. Therefore several studies suggest that various inflammatory mediators including cytokines, platelet activating factor, and reactive oxygen species contribute to the pathological process of meningitis, and the development of neuronal injury [7,8]. Nitric oxide (NO) may have some important pathophysiological effect during bactrial meningitis [9].

Nitric oxide (NO) is an uncharged molecule composed of seven electrons from nitrogen and eight electrons from oxygen. NO exhibits the potential to act as either an oxidizing or reducing agents [10]. NO is produced by the oxidation of the terminal guanidine group of L-arginine in the presence of oxygen and nicotinamide adenine dinucleotide phosephate (NADPH) by a family of enzymes Known as nitric oxide synthase (NOS2) [11].NO is not a stable substance, and it converts into 
nitrite and nitrate in 5-10 seconds. NO may play role in microwaves cellular injury, cerebral edema, C.S.F pleocytosis, neurological injury and necrotic cell death in oligodendroglias [9$12]$.

The mechanisms responsible for damage in the central nervous system are not yet completely understood. In some experimental studies, it was observed that NO destroyed the blood-brain barrier either directly or indirectly by the effect of TNF-alpha [13]. Another possible scenario is that bacterial DNA stimulates the inflammatory response and activates genes connected with the anti-inflammatory response and cell differentiation. Toll-like receptors (TLRs) play a significant role in this response; during a bacterial infection, these receptors activate the migration of microglia and leucocytes to the CNS [14].

\section{Aim of the study:}

In this study, we aimed to measure the level of nitric oxide (nitrite) in serum and CSF of the patients with acute meningitis to assess its role in the differentiation between bacterial and viral meningitis.

\section{PATIENTS AND METHODS}

The present study included 50 patients (27 males and 23 females), their age ranged from 15 to 55 years. All patients were admitted to Fever Hospital with picture suggesting of acute meningitis.

\section{Patients were excluded if they had :}

1- Antibiotic treatment before admission.

2- Administration of corticosteroid before admission.

3- Traumatic C.S.F punctures.

4- Duration of symptoms more than 72 hours.

Patients were classified into three groups according to CSF analysis :

Group I: composed of 22 patients with viral meningitis.

Group II: composed of 18 patients with bacterial meningitis.

Group III: (control group): In addition 10 subjects were included as control group (GIII). They were well matched with age and sex of patients. In this group the lumbar punctures were done for surgical purposes as hernial or testicular operations.
Immediately after admission, patients were subjected to the followings:

- Through clinical examination with great attention directed towards the nervous system.

- Lumber puncture was done using sterile lumber puncture needles. Samples of C.S.F and blood samples were collected for the following investigations:

- CSF total leucocytic count (ILC) and

- CSF total protein by tubidimetric method using tricholoroacetic acid [15].

- CSF and Serum glucose using ADIVA 1650 autoanalyzer (siemens medical solution Diagnostics).

- CSF gram stain and bacterial culture.

- Serum high sensitivity CRP (hs CRP) was determined by particle enhanced immunonephelometry using BN Prospec (siemens medical solutions Diagnostics). The intra assay precision ranges from 2.3 to 4.47 . CV, inter- assay precision ranges from 2.1 to 5.77. $\mathrm{CV}$ and analytical sensitivity is $0.175 \mathrm{mg} / \mathrm{l}$. CRP levels $>3 \mathrm{mg} / \mathrm{l}$. was considered positive [16].

- Blood: E.S.R, C.R.P, protein, total leucoctic count.

- Nitric oxide (nitrite) in C.S.F and serum was performed by using the nitric colorimetric method (Biodiagnostie Nitrite Assay Kit).

\section{Statistical analysis:}

Data were entered, checked and analyzed using SPSS version 10.0 (Statistical Package for the Social Sciences, Chicago, IL). Data were expressed as number and parentage for qualitative variables, mean \pm standard deviation for quantitative ones. Independent sample $\mathrm{t}$ test and paired sample $\mathrm{t}$ test were used as appropriate for analysis of results. $\mathrm{P}<0.05$ was considered significant.

\section{RESULTS}

Fifty patients (27 males, 23 females) were included in this study. Twenty two patients had viral meningitis and eighteen patients had bacterial meningitis according to CSF parameters - As regard the bacteriological results of CSF examination of patients with bacterial meningitis, the causative organism could be identified in 16 of the 18 patients. The diagnosis of the other 2 patients was based on the ground of typical CSF findings of bacterial meningitis. Staining of the CSF deposit with gram stain was positive in $100 \%$ of patients with bacterial meningitis, while 
the culture of CSF was positive in $88.8 \%$ of patients.

The CSF nitrite, protein, glucose, lymphocyte and WBC values of the patients and control group are shown in Table 3.

Nitrite level in the CSF samples of patients with bacterial meningitis were significantly elevated in comparison to viral meningitis group and control group $(\mathrm{P}<0.01, \mathrm{P}<0.01$, respectively). However, no significant elevations were found in patients of viral meningitis $(\mathrm{P}>0.05)$ compared to control.
There was significant differences of protein and glucose between groups $(\mathrm{P}<0.01)$.

We investigated the correlations between nitrite levels and WBC count; protein ; glucose level of C.S.F. In bacterial meningitis a positive correlation was found between nitrite levels and WBC count $(\mathrm{r}=0.834, \mathrm{P}<0.001)$, protein $(\mathrm{r}=$ $0.866, \mathrm{P}<0.001)$. A negative correlation was found between nitrite and glucose levels ( $r=$ $0.312, \mathrm{P}<0.05)$. There was a positive correlation between serum CRP and serum nitrite level $(\mathrm{r}=0.964-\mathrm{P}<0.001)$.

Table (1): The demographic data of different groups

\begin{tabular}{|l|c|c|c|}
\hline & $\begin{array}{c}\text { Viral meningitis } \\
(\mathbf{n = 2 2})\end{array}$ & $\begin{array}{c}\text { Bacterial meningitis } \\
(\mathbf{n = 1 8})\end{array}$ & $\begin{array}{c}\text { Control } \\
(\mathbf{n}=\mathbf{1 0})\end{array}$ \\
$\begin{array}{l}\text { Age } \\
\mathrm{X} \pm \mathrm{SD}\end{array}$ & $18.02 \pm 15.19$ & $12.2 \pm 11.82$ & $26 \pm 7.12$ \\
range & $(15 .-55 \mathrm{y})$. & $(15-65 \mathrm{y})$. & $(18-40 \mathrm{y})$. \\
Sex & 12 & 9 & 6 \\
$\quad$ Male & 10 & 9 & 4 \\
Female & & & 6 \\
\hline
\end{tabular}

Table (2): Different clinical parameters in the viral and the bacterial groups

\begin{tabular}{|l|c|c|c|}
\hline \multicolumn{1}{|c|}{ Parameter } & $\begin{array}{c}\text { Viral meningitis } \\
(\mathbf{n = 2 2})\end{array}$ & $\begin{array}{c}\text { Bacterial meningitis } \\
(\mathbf{n = 1 8})\end{array}$ & P value \\
\hline Fever. & $20(90.9 \%)$ & $18(100 \%)$ & 0.55 \\
\hline Headache. & $16(72.7 \%)$ & $15(83.3 \%)$ & 0.67 \\
\hline Photophobia. & $2(9.1 \%)$ & $6(33.3 \%)$ & 0.13 \\
\hline Vomiting. & $16(72.7)$ & $12(66.6)$ & 0.94 \\
\hline Neck stiffness. & $15(68.2 \%)$ & $14(77.7 \%)$ & 0.75 \\
\hline Kernig's sign. & $10(45.4 \%)$ & $12(66.6 \%)$ & 0.30 \\
\hline Brudziniski's sign. & $7(31.8 \%)$ & $11(61.1 \%)$ & 0.12 \\
\hline Convulsions. & $3(13.6 \%)$ & $5(27.7 \%)$ & 0.47 \\
\hline Confusion. & $13(59.1 \%)$ & $10(55.5 \%)$ & 0.92 \\
\hline Rash. & $2(9.1 \%)$ & $3(16.6 \%)$ & 0.81 \\
\hline
\end{tabular}


Table (3): Laboratory finding of CSF and serum in bacterial and viral compared to control groups

\begin{tabular}{|c|c|c|c|c|c|c|}
\hline $\begin{array}{l}\text { CSF / serum } \\
\text { Parameters }\end{array}$ & $\begin{array}{c}\text { Viral group } \\
(\mathbf{n}=22)\end{array}$ & $\begin{array}{c}\text { Bacterial } \\
\text { group } \\
(\mathbf{n}=18)\end{array}$ & $\begin{array}{c}\text { Control } \\
\text { group } \\
(\mathrm{n}=10)\end{array}$ & P1 & P2 & $\mathbf{P 3}$ \\
\hline \multicolumn{7}{|l|}{ CSF } \\
\hline $\begin{array}{l}\text { Nitric oxide } \\
\text { (umol/l) }\end{array}$ & $12.6 \pm 0.64$ & $17.078 \pm 1.78$ & $3.38 \pm 0.39$ & $>0.5$ & $<0.01$ & $<0.01$ \\
\hline WBCs (per ml) & $125.68 \pm 46.35$ & $2949.28 \pm 1497.7$ & $4.7 \pm 2.22$ & $<0.001$ & $<0.01$ & $<0.01$ \\
\hline Protein (mg/dl) & $41.91 \pm 5.73$ & $152.33 \pm 55.713$ & $28.8 \pm 7.2$ & $<0.001$ & $<0.01$ & $<0.01$ \\
\hline Glucose (mg/dl) & $68.5 \pm 8.20$ & $42.39 \pm 7.12$ & $61.5 \pm 5.4$ & $>0.05$ & $<0.01$ & $<0.01$ \\
\hline \multicolumn{7}{|l|}{ Serum } \\
\hline $\begin{array}{l}\text { Nitric oxide } \\
\text { (umol/l) }\end{array}$ & $3.59 \pm 0.51$ & $10.64 \pm 0.89$ & $11 \pm 0.7$ & $<0.001$ & $<0.001$ & $<0.001$ \\
\hline $\begin{array}{l}\text { WBCs } \\
\text { (cell/cmm) }\end{array}$ & $\begin{array}{l}6146.9 \pm \\
1946.85\end{array}$ & $\begin{array}{c}17438.05 \pm \\
5548.16\end{array}$ & $\begin{array}{c}6146.9 \pm \\
1434.22\end{array}$ & $<0.001$ & $<0.001$ & $<0.001$ \\
\hline $\begin{array}{l}\begin{array}{l}\text { Platelets } \\
(\text { cell/cmm) }\end{array} \\
\end{array}$ & $\begin{array}{c}118323.691 \pm \\
4173.25 \\
\end{array}$ & $\begin{array}{c}104751.93 \pm \\
20136.8 \\
\end{array}$ & $\begin{array}{c}175140.91 \\
\pm 164.31 \\
\end{array}$ & $<0.001$ & $<0.001$ & $<0.001$ \\
\hline CRP (mg/dl) & $14.77 \pm 4.74$ & $95.17 \pm 26.60$ & $\begin{array}{c}1.14 \pm \\
0.359798\end{array}$ & $<0.001$ & $<0.001$ & $<0.001$ \\
\hline
\end{tabular}

P1: viral vs control

p2: bacterial vs control

p3: viral vs bacterial

Table (4): Correlation between viral CSF nitric oxide (nitrite) and other viral CSF parameters

\begin{tabular}{|l|c|c|}
\hline \multirow{2}{*}{ Parameter } & \multicolumn{2}{|c|}{ Viral CSF nitrite (m mol / L) } \\
\cline { 2 - 3 } & $\mathbf{R}$ & $\mathbf{P}$ \\
\hline Viral CSF WBCs (per ml) & 0.251 & $>0.05$ \\
\hline Viral CSF protein (mg/dl) & 0.374 & $>0.05$ \\
\hline Viral CSF glucose (mg/dl) & 0.221 & $>0.05$ \\
\hline
\end{tabular}

Table (5): Correlation between viral serum nitric oxide (nitrite) and viral serum CRP

\begin{tabular}{|l|c|c|}
\hline \multirow{2}{*}{ Parameter } & \multicolumn{2}{|c|}{ Viral serum } \\
\cline { 2 - 3 } & $\mathbf{R}$ & $\mathbf{P}$ \\
\hline Viral serum CRP $(\mathrm{mg} / \mathrm{dl})$ & 0.310 & $>0.05$ \\
\hline
\end{tabular}

Table (6): Correlation between bacterial CSF nitric oxide (nitrite) and other bacterial CSF Parameters

\begin{tabular}{|l|c|c|}
\hline \multirow{2}{*}{\multicolumn{1}{|c|}{ Parameter }} & \multicolumn{2}{|c|}{ Bacterial CSF nitrite (m mol/L) } \\
\cline { 2 - 3 } & $\mathbf{R}$ & $\mathbf{P}$ \\
\hline Bacterial CSF protein $(\mathrm{mg} / \mathrm{dl})$ & 0.866 & $<0.001$ \\
\hline Bacterial CSF WBCs (per u) & 0.834 & $<0.001$ \\
\hline Bacterial CSF glucose (mg/dl) & 0.312 & $>0.05$ \\
\hline
\end{tabular}

Table (7): Correlation between bacterial serum nitric oxide (nitrite) and bacterial serum CRP

\begin{tabular}{|l|c|c|}
\hline \multirow{2}{*}{ Parameter } & \multicolumn{2}{|c|}{ Bacterial serum nitrite $(\mathrm{m} \mathrm{mol} / \mathrm{L})$} \\
\cline { 2 - 3 } & $\mathrm{R}$ & $\mathrm{P}$ \\
\hline Bacterial serum CRP $(\mathrm{mg} / \mathrm{dl})$ & 0.946 & $<0.001$ \\
\hline
\end{tabular}




\section{DISCUSSION}

Meningitis is a severe infectious disease that results from inflammation of the membranes surrounding the brain and the spinal cord. It may be caused by several microorganisms. Meningitis usually results from a viral infection which is the main cause of aseptic meningitis. Moreover, the main cause of septic meningitis is bacterial meningitis (BM). Less commonly, a fungal infection may result in fungal meningitis i.e. also, a part of aseptic disease [17].

Currently, interest in the role of NO in the pathogensis of bacterial meningitis responsible for cell death $[14,18]$. A study of the murine model of meningitis indicated that Escheichia coli stimulate iNOs expression in the brains of investigated animals and that the resulting NO may influence the survival of bacteria inside the macrophages [19] Furthermore during the course viral infections.

An increased level of radicals (reactive oxygen species, ROS) has been observed. The published data from a murine model investigation of herpetic encephalitis identified the role of oxidative stress in neuronal injury [20].

This study was conducted in Fever Hospital to measure the level of nitric oxide (nitrite) in serum and CSF of the patients with acute meningitis and to analyze the correlation between its level and both the clinical and the laboratory parameters in a trial to differentiate between bacterial and viral meningitis.

In this study we found that the CSF NO level in the bacterial group was significantly higher than that of the viral group. These results indicate that the bacterial meningitis leads to increased in production of $\mathrm{NO}$ in the CSF. In contrast, patients with viral meningitis did not show high CSF NO concentrations, suggesting that viral factors do not cause substantial increase of NO production in CSF compartments. These observations were in agreement with those of Murawska-Ciałowicz et al. [21] and Mahmoud et al. [22] who reported that there was an increase in the levels CSF NO metabolites (nitrite) in patients with bacterial meningitis than in those with viral meningitis. Also, Murawska et al. [23] and Qureshi et al. [24] found that an increase in level of CSF NO was not observed in viral meningitis.

In this study, we found that bacterial CSF WBCs count was higher than that of viral CSF WBCs count (mean of 2949.28 for bacterial cases and mean of 125.68 for viral cases). Also, we found that the type of CSF WBCs was different in the 2 types of meningitis (it was found to be mainly polymorphs (PMNLs) in the bacterial meningitis, but it was found to be mainly lymphocytes in the viral type). The same results were reported by Abro et al. [25] who noted that, in bacterial meningitis, CSF WBCs, usually polymorphs, increases significantly with mild increase in CSF WBCs count, mostly lymphocytes in the viral type.

In the present study, we found that bacterial meningitis CSF protein content was higher than that of viral cases (a mean of 152.33 for bacterial cases and a mean of 41.91 for viral cases). Also, we found that higher levels of CSF protein parallel the severity of the cases. The same results were reported by Feigin and Pearlman et al. [26]. This could be explained by that the meningeal inflammation increase the flow of the proteins into the CSF. Also, tissue destruction may increase the CSF proteins.

In our study, we found that bacterial meningitis CSF glucose content was lower than that of viral cases (a mean of 42.39 for bacterial cases and a mean of 68.5 for viral cases). Similar result was reported by Tunkle et al. [27], who reported that CNS bacterial infections can cause lowered CSF glucose levels, although CSF glucose levels are usually normal in CNS viral infections.

The low CSF glucose levels may be explained by the inhibition of mitochondrial respiration that enhance the anaerobic glycolysis through excessive NO production [28,29].

In this work, nitric oxide (nitrite) level, generally, was found to be higher in serum than in CSF of all groups. Also, we found that there was a highly significant difference $(\mathrm{P}<0.001)$ between serum NO (nitrite) and CSF NO in all groups. It was also found that levels of both serum NO and CSF NO were higher in bacterial meningitis. These nitric oxide $\mathrm{CSF} / \mathrm{serum}$ ratios and indices are suggestive of its local production in the CNS as well as its passage through the disturbed blood brain barrier. The same result was detected by Hamed et al. [30].

In this work, in the bacterial group, the serum level of the nitric oxide (nitrite) was found to be higher in patients with Gram positive CSF cultures than in patients with negative CSF cultures. This could be explained by that the 
nitric oxide (NO) production is related to the presence of the organism. The same result was reported by Bell and McCromick [31]. In this work, we found that bacterial blood WBCs count was higher than that of viral cases (a mean of 17438.05 for bacterial cases and a mean of 6146.9 for viral cases). However, Bell and McCormick [31] reported that leucocytosis does not necessarily differentiate bacterial from aseptic meningitis since the later can be also associated with significant leucocytosis.

In this study, we found that, there was a positive highly significant correlation between CSF NO (nitrite) and CSF protein in both bacterial $(\mathrm{r}=0.866, \mathrm{p}<0.001)$ and viral meningitis $(\mathrm{r}=0.97$, $\mathrm{p}<0.001)$. Also, a positive highly significant correlation was found between CSF NO (nitrite) and CSF WBCs in both bacterial $(\mathrm{r} 0.834, \mathrm{p}<0.001)$ and viral meningitis $(\mathrm{r}=0.922, \mathrm{P}<0.001)$. van Furth et al. [32] Murawska-Ciałowicz et al. [21] and Cetin et al. [33] reported similar results in their studies.

However, Mahmoud et al. [22] found no correlation between CSF nitrite levels and CSF white blood cells count or protein levels. Also, Kornelisse et al. [34] and Duke et al. [35] did not detect a correlation between CSF nitrite level and leukocyte count. In these studies, it was emphasized that a "major source of nitrite was not inflammatory cells".

These positive correlations between CSF nitriteleukocytes and nitrite-protein levels in meningitis could be explained by that during episodes of meningitis especially the bacterial, TNF-alpha in CSF induces NO syntheses and consequently the production of NO, which in turn, mediates the increase in the permeability of the blood-brain barrier. This, in turn, will increase the entry of proteins and inflammatory cells (leukocytes) into the CSF compartments leading to the observed positive correlations between CSF nitrite-leukocytes and nitrite-protein levels in meningitis. The same explanation was assumed by Cetin [33].

In conclusion, the higher level of nitric oxide (nitrite) in both serum and CSF of cases of bacterial meningitis represents a rapid, easy and cheap method for the differentiation between viral and bacterial causes of acute meningitis.

Funding:Non.

Conflict of interst:Non.

Ethical approval: Approved.

\section{REFERENCES}

1. Allan R, Tunkel W, Scheld M . Acute meingitis. Princeiples and Practice of infections Disease (Eds. Mandell Gl, Bannet JE, Dolin R) Charchill Livigstone, New York 2000; PP: 956-996.

2. Rosskl . Acute bacterial meningitis. Semin Neurol 2000; 20-293-306.

3. Sormunen P, Kallio Ml, Kilpi , Pettola H . Creactive protein is useful in distinguishing gram stain-negative bacterial meningitis from viral meningitis in children. J Med 1999; 328, 2128.

4. Leib SL, Tauber MG . Pathogenesis of bacterial meningitis. Infect Dis Clin North Am1990; 13: 527 -48.

5. Spano A, Harrell F , Durack DI . Differential diagnosis of acute meningitis. Analysis of the predictive value of initial observation. JAMA 1989; 262 : 2700-2707.

6. Lindquist L, Linné T, Hansson LO, Kalin M, Axelsson G. Value of cerebrospinal fluid analysis in the differential diagnosis of meningitis: a study in 710 patients with suspected central nervous system infection. Eur J Clin Microbiol Infect Dis. 1988 ;7(3):374-80.

7. Braun JS, Tuomanen E . Molecular mechanisms of brain damage in bacterial meningitis. Adv Pediatr Infect Dis 1999;14: 49-71.

8. Tureen $\mathbf{J}$. Effect of recombianant human tumour necrosis factor- alpha on cerebral oxygen uptake. Cerebrospinal fluid lactate, and cerebral blood flow in the rabbit. Role of nitric oxide. J Clin Invest 1995; 95 : 1086-91.

9. Komellsse RF, Hoekman K, Visser JJ, Hop Wc, Huijmans JG, van der straiten, de Groote $\mathrm{R}$. the role of nitric oxide in bacterial meningitis in children. J Infect Dis1996; 174 : 120-6.

10. Beckman Js , Koppenol WH . Nitric oxide, Superoxide, and Peroxynitrite: the good, the bad, and the ugly. Am J Physiol 1996; 271: c1424-c1437.

11. Arzumanian V, Stankevicius E, Kevelaitis E, Kevelaitis E . Mechanisms of nitric oxide synthesis and action in cells. Medicine 2003; 39(6): 535-41.

12. Pifster Hw, Bematowiz A, Kodel U, Wick M - Nitric oxide production in bacterial meningitis. J Neurol Neurosurg Psychiatry 1995; 58: 384-5.

13. Freyer D, Manz R, Ziegenhorn A, Weih M, Angstwurm K, Döcke WD et al. : Cerebral endothelial cells release TNF-alpha after stimulation with cell wall of streptococcus pneumonia and regulate inducible nitric oxide synthase and ICAM-1 expression via outocrin loops. J Immunol1999; 63:4308-14. 
14. Gerber J , Nau R . Mechanisms of injury in bacterial meningitis. Curr Opin Neurol 2010; 23(3): 312-8.

15. Shahanigan S, Brown PI, ASH Ko . Turbidimetric Measurement of total urinary Proteins. Am J Clin Pathol 1984; 81: 651.

16. Chenillot O, Henny J, Steinmetz J, Herbeth B, Wagner C, Siest G. high sensitivity c-reactive protein : Biological variations and reference limits. Clin Chem Lab Meal 2000; 38-1011.

17. Ryan K , Ray G . Local system infection. Sherries. Medical Microbiology, In Ryan K (ed.). $4^{\text {th }}$ ed., 2004; PP:867-879. McGrow Hill, Edmical Publishing Division.

18. Weber JR , Tuomanen EI . Cellular damage in bacterial meningitis: an interplay of bacterial and host driven toxicity. $J$ Neuroimmunol 2007; 184(1-2):45-52

19. Mittal R, Gonzalez-Gomez I, Goth KA, Prasadarao . NV. Inhibition of inducible nitric oxide controls pathogen load and brain damage by enhancing phagocytosis of Escherichia coli $\mathrm{K} 1$ in neonatal meningitis. Am J Pathol 2010; 176(3): 1292-305

20. Schachtele SJ, Hu S, Little MR, Lokensgard JR . Herpes simplex virus induces neural oxidative damage via microglial cell Tolllike receptor-2. J Neuroinflammation 2010; 28;7:35.

21. Murawska-Ciałowicz E, Szychowska Z, Tr busiewicz B. Nitric oxide production during bacterial and viral meningitis in children. Int J Clin Lab Res 2000; 30:127-31

22. Mahmoud MK, Fawy G, Salah K. Recent advances in the pathophysiology of meningitis in children. Alexandria journal of pediatrics2005; 19(1):13- 16.

23. Murawska E, Szychowska Z, Trebusiewicz B.Nitric oxide (NO) in children with meningitis. Przegl Epidemiol 1997; 51(3):309-15.

24. Qureshi GA, Baig SM, Bednar I, Halawa A, Parvez SH. The neurochemical markers in cerebspinal fluid to differentiate between aseptic and tuberculous meningitis. Neurochem Int 1998;32:197-203.

25. Abro A, Saleh A, Haseb H . Cerebro-pinal fluid analysis acute bacterial versus viral meningitis. Pak J Med Sci 2008; 24 (5):645650 .
26. Feigin RD, Pearlman E . Bacterial meningitis beyond the neonatal period. In: Textbox of pediatric Infectious Diseases. Edited by: Feigin RD and Cherry JD $4^{\text {th }}$ eds.1998; W.B Saunders Company, Philadelphia.

27. Tunkel AR, Hartman BJ, Kaplan SL, Kaufman BA, Roos KL, Scheld WM, Whitley RJ. "practice guidelines for the mangment of bacterial meningitis". Clinical Infectious Diseases2004; 39 (9):1267-84.

28. Albina JE, Mastrofrancesco B . Modulation of glucose metabolism in macrophages by products of nitric oxide synthase. Am J Physiol1993; 264:C1 594-9

29. Amaee FR, Comis SD, Osborne MP, Drew S, Tarlow MJ. Possible invovlment of nitric oxide in the sensorrineural hearing loss of bacterial meningitis. Acta Otolaryngol (Stohk)1997;117:329-36

30. Hamed SA, Hamed EA, Zakary MM. Oxidative stress and $\mathrm{S} 100 \mathrm{~B}$ protein in children with bacterial meningitis. $B M C$ neurology 2009;8(9):51.

31. Bell E , McCromick F . Bacterial meningitis. In: Neurological infection in children, ${ }^{2 n d}$ Ed 1981.

32. van Furth AM, Seijmonsbergen EM, Groeneveld PH, van Furth R, Langermans JA. Levels of nitric oxide correlate with high levels of tumor necrosis factor alpha in cerebrospinal fluid samples from children with bacterial meningitis. Clin infect Dis 1996 ;22:876-8.

33. Cetin K, Erol S, Aksoy H, Tasyaran MA.Relation of cerebrospinal fluid nitric oxide levels to prognosis and differential diagnosis of meningitis. Turk J Med Sci 2002;32:385-390.

34. Kornelisse RF, Hoekman K, Visser JJ, Hop WC, Huijmans JG, van der Straaten PJ. The role of nitric oxide in bacterial meningitis in children. J Infect Dis 1996; 174-120-6.

35. Duke T, South M, Stewart A. Activation of the L-arginine nitric acid pathway in severe sepsis. Arch Dis 1997; 76:203.

Peer Reviewer: Eman Elshamy:Professor of Tropical Medicine and Hepatogastroenterology ,Faculty of Medicine ,Zagazig Universty,Egypt.

Editor:Tarik Zaher:Professor of Tropical Medicine and Hepatogastroenterology ,Faculty of Medicine ,zagazig Universty ,Egypt. 